\title{
DIGENEAN METACERCARIA (TREMATODA, DIGENEA, LEPOCREADIIDAE) PARASITIZING “COELENTERATES” (CNIDARIA, SCYPHOZOA AND CTENOPHORA) FROM SOUTHEASTERN BRAZIL
}

\author{
André Carrara Morandini ${ }^{I}$; Sergio Roberto Martorelli ${ }^{2}$; Antonio Carlos Marques ${ }^{I}$ \& Fábio Lang da Silveira ${ }^{l}$ \\ ${ }^{1}$ Instituto de Biociências da Universidade de São Paulo \\ Departamento de Zoologia \\ (Caixa Postal 11461, 05422-970, São Paulo, SP, Brazil) \\ ${ }^{2}$ Centro de Estudios Parasitologicos y Vectores (CEPAVE)
}

(2 Nro. 584 (1900) La Plata, Argentina)

e-mails: acmorand@usp.br, sergio@cepave.com.ar, marques@ib.usp.br, fldsilve@ib.usp.br

\section{A B S T R A C T}

Metacercaria specimens of the genus Opechona (Trematoda: Digenea: Lepocreadiidae) are described parasitizing "coelenterates" (scyphomedusae and ctenophores) from Southeastern Brazil (São Paulo state). The worms are compared to other Opechona species occurring on the Brazilian coast, but no association has been made because only adult forms of these species have been described. Suppositions as to the possible transference of the parasites are made.

\section{R ESUMO}

Exemplares de metacercárias do gênero Opechona (Trematoda: Digenea: Lepocreadiidae) são descritos parasitando "celenterados" (cifomedusas e ctenóforos) no sudeste do Brasil (estado de São Paulo). Os vermes foram comparados a outras espécies de Opechona ocorrentes no litoral brasileiro, porém nenhuma associação foi realizada devido às demais espécies terem sido descritas a partir de exemplares adultos. São apresentadas suposições sobre as possíveis formas de transferência dos parasitas.

Descriptors: Metacercaria, Cnidaria, Ctenophora, South Atlantic.

Descritores: Metacercaria, Cnidaria, Ctenophora, Atlântico Sul.

\section{INTRODUCTION}

Cnidarian parasites have been little studied, but they are known to include a variety of animal groups: Cestoda (Moestafa \& McConnaughey, 1966; Phillips \& Levin, 1973), Trematoda (Stunkard, 1969, 1983), Pycnogonida (Child \& Harbison, 1986), other Cnidaria (Bouillon, 1987), and Lepadomorpha (Pagès, 2000). Thiel (1976) commented on the parasites, commensals and symbionts of scyphomedusae. The same lack of knowledge also applies to the ctenophores (GESAMP, 1997: 21), though some have already been reported as parasites [Cnidaria (Crowell, 1976), and Trematoda (Stunkard, 1980; Yip, 1984)]. The most usual parasitic association with "coelenterates" concerns the crustaceans of the Hyperiidea (Amphipoda) family (Harbison et al., 1977).
Some parasites of pelagic "coelenterates" are known for the South Atlantic region (Martorelli, 1996, 2001). Most of these parasites occur in hydromedusae (Martorelli, 1991, 1996, 2001; Girola et al., 1992; all studies recording digeneans) but only one report relates to scyphomedusae (Vannucci-Mendes, 1954; record of a cestode).

Digenean worms present a complex life cycle, including several intermediate hosts (e.g. Martorelli \& Cremonte, 1998), but usually they have three hosts during their life history (Martorelli, 2001). The life cycles of these parasites, especially in relation to their intermediate hosts, are poorly known. The difficulties involved in arriving at complete descriptions of their life cycles are due to the complexity of their life histories, inhabiting as they do a succession of prey-predators or actively penetrating potential available host-species present in the environment. There is, thus, too general a lack of ecological knowledge, both of extensive food-chaims 
and of extensive faunistic surveys, to enable any comparison to be made with the life-histories of digeneans, in the attempt to establish potential hosts (e.g. Martorelli \& Cremonte, 1998). A review of our knowledge of digeneans parasitizing jellyfish and ctenophores is presented by Martorelli (2001).

This study describes the occurrence of digenean parasites in ctenophores and is also the first record of these parasites in scyphomedusae, both intermediate hosts, from the South Atlantic (São Paulo State, southeastern Brazil).

\section{Material And Methods}

All the hosts were collected off Cananéia $\left(25^{\circ} \mathrm{S}-48^{\circ} \mathrm{W}\right)$ (São Paulo State, southeastern Brazil) and were captured on the water surface with a hand net and observed in the laboratory immediately afterwards.

Medusae of the scyphozoans (Cnidaria, Scyphozoa) Chrysaora lactea Eschscholtz, 1829 (Semaeostomeae, Pelagiidae) and Lychnorhiza lucerna Haeckel, 1880 (Rhizostomeae, Lychnorhizidae) were surveyed for a period of 33 months, from October/1999 to June/2002.

The ctenophores (Ctenophora) Mnemiopsis maccradyi Mayer, 1900 (Tentaculata, Lobata, Bolinopsidae) and Beroe sp. (Nuda, Beroida, Beroidae) were collected at irregular intervals when they were most frequent.

The parasites were collected by dissociating the live tissue from the hosts and transferring it by pipette to Petri dishes containing filtered seawater. Some specimens were preserved directly in $4 \%$ formaldehyde solution in seawater (fsw) and others were fixed in heated fsw. Pieces of the hosts containing worms were cut out and preserved in the same way.

Preserved parasite specimens were mounted on permanent slides following Mahoney (1973) and stained with Harris haematoxilin, Langeron alcoholic carmine or Mayer's paracarmin. Specimens prepared for scanning electron microscopy (SEM) were re-fixed for 1 hour in $1 \%$ Osmium tetroxide, washed three times in Tanic acid, dehydrated, dried to their criticalpoint and mounted on stubs. They were then coated with $10 \mathrm{~nm}$ of gold in a Balzers S-SCD 050 sputter coater. Specimens were examined under a Zeiss DSM 940 SEM.

Live specimens were photographed under a Zeiss Axioskop microscope connected to a computer and drawings were made with a Nikon Optiphot microscope with camera lucida. All measurements were made of ten preserved specimens and are given in micrometers, with the mean and standard deviation in parentheses.
Voucher specimens were deposited at the Parasite Collection of the Museu de Zoologia da Universidade de São Paulo (MZPC 5938a, b).

\section{RESUlts \\ Biological Data}

During the 33 months of sampling of scyphozoan jellyfish, only specimens collected in October and November 2000, and September 2001 were found to be infected by the digenean. The ctenophores Mnemiopsis maccradyi collected in February, July, August and September 2001, and Beroe sp. collected in February 2004, were also infected by parasites.

The metacercariae were found in the gastric filaments of both medusa species, in the gonadal tissue of Chrysaora lactea, and in the mesoglea (around the canals and the pharynx) of the ctenophores. Prevalence and intensity of infection for the four hosts are presented in Table 1.

Table 1. Prevalence and intensity of metacercaria infecting "coelenterates" from the Cananéia estuarine region (São Paulo State, Brazil). $\mathrm{I}=$ Intensity $=$ number of parasites in a single host; $\mathrm{n}=$ total number of hosts analyzed; $\mathrm{P}=$ total number of hosts infected; $\% \mathrm{P}=$ Prevalence $=$ number of hosts infected (P) divided by the number of hosts examined (Intensity and Prevalence according to Margolis et al., 1982 and Bush et al., 1997).

\begin{tabular}{lllll}
\hline \hline Species & $\mathbf{N}$ & $\mathbf{P}$ & $\mathbf{\% P}$ & $\mathbf{I}$ \\
\hline Chrysaora lactea & 38 & 4 & 10.5 & $2-16$ \\
Lychnorhiza lucerna & 285 & 1 & 0.35 & 1 \\
Mnemiopsis maccradyi & 48 & 6 & 12.5 & $1-6$ \\
Beroe sp. & 5 & 4 & 80 & $1-13$ \\
\hline
\end{tabular}

Nematocysts (birhopaloid type II) from the gastric filaments of the host $C$. lactea were observed over the tegument of both live and preserved specimens of the parasite found in the jellyfish species (Figs 1-2).

Isolated metacercariae moved freely as in peristaltic movement, apparently not at all or little constrained by the external hardened tegument. These isolated metacercariae were able to reinfest the same medusa after being removed from their host.

Medusae of $C$. lactea and specimens of $M$. maccradyi and Beroe sp. were sometimes observed near each other in the estuary and, occasionally, some medusae of C. lactea were seen feeding on the ctenophores; Beroe sp. also feed on $M$. maccradyi. 
Taxonomic Status

Class Trematoda Rudolphi, 1808

Subclass Digenea Carus, 1863

Family Lepocreadiidae Odhner, 1905

Genus Opechona Looss, 1907

\section{Description of the Parasite}

Unencysted metacercariae with body oval, pyriform in some live specimens from 164-202 $\mu \mathrm{m}$ $(182 \pm 0.011)$ in length, $80-128 \mu \mathrm{m}(102 \pm 0.014)$ in width (Fig. 7). The body becomes more elongated in specimens with protruding oral sucker $(246-450 \mu \mathrm{m}$ in length). Tegument spinous (Figs. 1, 3-4); spines embedded in tegument, with triangular extremity protruding, concave, abundant, arranged in radial verticils; contiguous verticils with somewhat alternate series of spines. Spiny tegument more dense anteriorly, becoming small and more widely spaced posteriorly. Anterior black disgorged eyespot pigment observed encircling pharynx (Figs. 4, 7). Oral sucker subterminal, oval, larger than ventral sucker. Nine radial globular to triangular papillae, internal rim with 1-3 non-organized series of spines; oral sucker 36-50 $\mu \mathrm{m}(42 \pm 0.004)$ in length, $39-48 \mu \mathrm{m}(43 \pm 0.003)$ in width (Figs. 4-5, 7). Mouth in the middle of oral sucker, with conspicuous muscular walls (Fig. 5). Muscular pharynx well-developed in the third anterior end, 26-36 $\mu \mathrm{m}(31 \pm 0.003)$ in length, $22-30 \mu \mathrm{m}(26 \pm$ 0.003 ) in width, with narrow alimentary canal (Figs. 4, 7), followed by a small esophagus. Pseudoesophagus present (30-40 $\mu \mathrm{m}$ in length) larger than esophagus (15-20 $\mu \mathrm{m}$ long). Caecal bifurcation behind esophagus, anterior to acetabulum. Two long lateral intestinal caeca, reaching posterior end, joining excretory vesicle to form uroproct (Fig. 7). Ventromedian acetabulum also spiny, with 9 radial globular to triangular papillae, $30-41 \mu \mathrm{m}(36 \pm 0.003)$ in length, $32-41 \mu \mathrm{m} \mathrm{(38 \pm 0.003)}$ in width (Figs. 6-7). Excretory vesicle tubular with spherical concretions bodies, extending from hindbody to the anterior edge of the acetabulum (Figs. 2, 7). The flame cell pattern was not observed. Excretory pore terminal with glandular sphincter. Primordia of the testis, oval, contiguous in mid-hindbody. Well developed cirrus sac present, with internal seminal vesicle and overlapping with the ventral sucker. Ovary oval with irregular edges in some specimens.

\section{Hosts and Geographical Area}

Locality: Cananéia, São Paulo State, Brazil (Western South Atlantic Ocean)

Coordinates: $25^{\circ} \mathrm{S}-48^{\circ} \mathrm{W}$

Host: Chrysaora lactea

Site of infection: gastric filaments and gonadal tissue
Host: Lychnorhiza lucerna

Site of infection: gastric filaments

Hosts: Mnemiopsis maccradyi and Beroe sp.

Site of infection: mesoglea

\section{DiscUSSION}

The metacercariae were related to the family Lepocreadiidae by virtue of the presence of remnants of an eyespot on each side of the pharynx, spinous tegument and I-shaped excretory bladder. The morphology of the specimens studied herein agrees with the definition of the genus Opechona. Bray \& Gibson (1990) reviewed this genus and gave a key that included nine species of Opechona sensu stricto characterized by the presence of uroproct. Later, Bray \& Crib (1998) described another species within this group, $O$. austrobacillaris in Pomatomus saltatrix (Pisces: Pomatomidae) from Australia.

The species studied now is, according to Bray \& Gibson (1990), more closely related to $O$. bacillaris (Molin, 1859) by having the body oval to elongated, pseudoesophagus longer than esophagus, oral sucker larger than ventral sucker, and the excretory vesicle reaching the intestinal bifurcation. $O$. bacillaris is a cosmopolitan species, its metacercariae having been previously reported in gelatinous plankton (Lebour, 1916; Reimer et al., 1971; Køie, 1975; Yip, 1984). Size and shape of the oral sucker (oval and slightly bigger than the ventral sucker) distinguish our specimens from $O$. bacillaris (in which it is bigger than the ventral sucker and infundibular).

As regards another species of metacercariae reported from gelatinous plankton, our specimens resemble $O$. pyriforme Linton, 1900 reported from the Mexican Caribbean Sea (Gómez del Prado-Rosas et al., 2000) and Opechona sp. described by Martorelli (2001) from the Argentinian coast. Our specimens differ from $O$. pyriforme (sensu Gómez del PradoRosas et al., 2000) mostly as regards body length, spine distribution and extension of the excretory vesicle. Our metacercariae differ from Opechona sp. (sensu Martorelli, 2001) by the body shape's being more oval, its suckers smaller and the pharyngeal eyespot's more posterior position instead of its prepharyngeal location in Opechona sp.

At present only three adult species of the genus Opechona have been reported in fish from the Brazilian coast: $O$. chloroscombri (Amato, 1983), $O$. bacillaris (Amato 1983, Wallet \& Khon, 1987) and Opechona sp. (Abdallah et al., 2002). Recently Fabio (2001) reported $O$. orientalis (Laiman, 1930) in Cephalopholis fulva (Linnaeus, 1758) (Pisces: Serranidae) from Angra dos Reis (Rio de Janeiro state, Brazil), but this species had already been transferred, because of its lack of the uroproct, to the genus Prodistomun Linton, 1910 (Bray \& Gibson, 1990). 

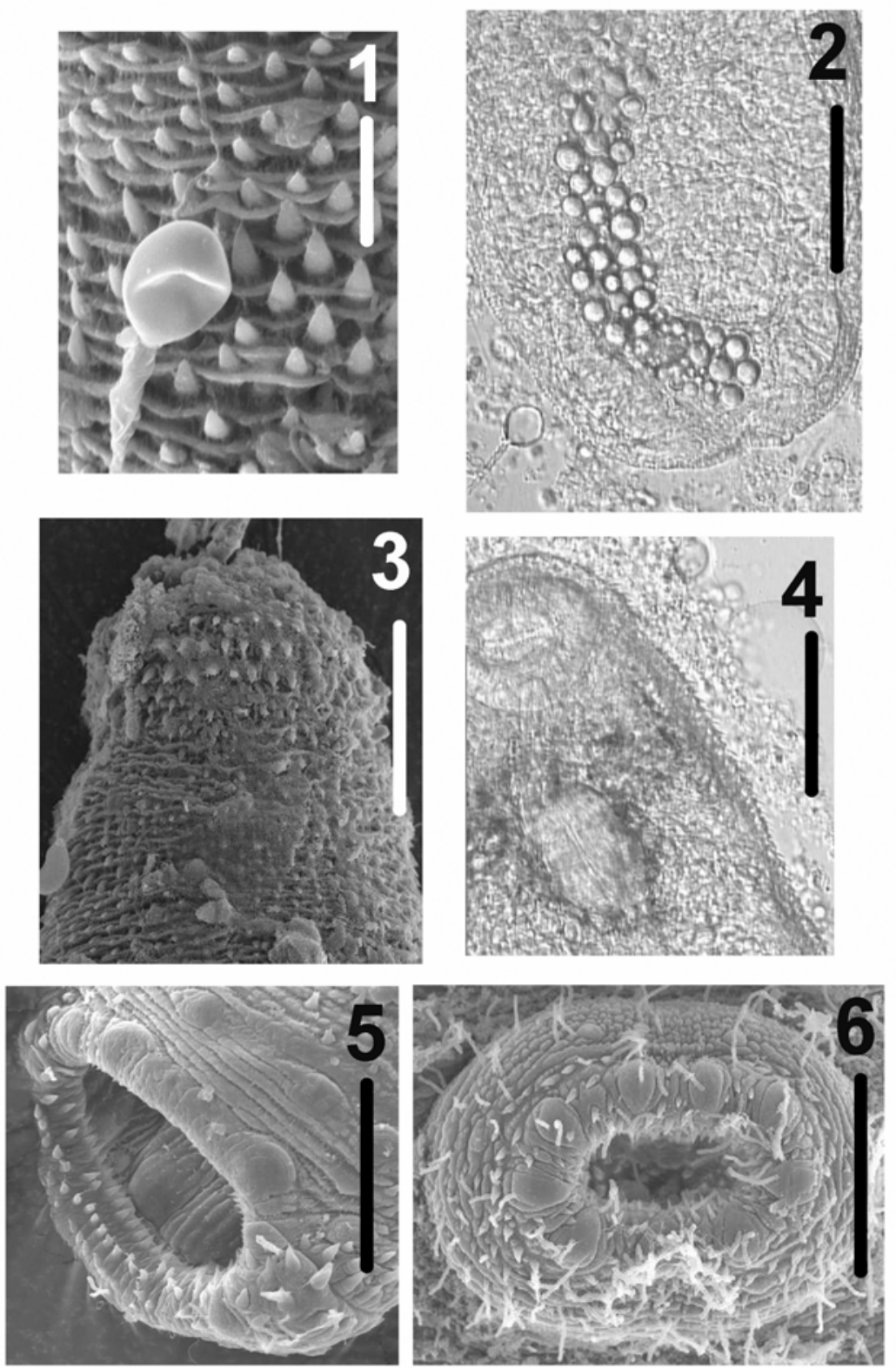

Fig. 1. Scanning electron micrograph of the surface of the metacercaria of Opechona sp., showing a nematocyst attached to the spinous tegument. Scale $=15 \mu \mathrm{m}$.

Fig. 2. Photomicrograph of a live specimen of the metacercaria of Opechona sp. in ventral view, showing a nematocyst near the body (lower left). Scale $=50 \mu \mathrm{m}$.

Fig. 3. Scanning electron micrograph of the surface of anterior part of the metacercaria of Opechona sp., showing the spinous tegument. Scale $=50 \mu \mathrm{m}$.

Fig. 4. Photomicrograph of the anterior part of a live specimen of the metacercaria of Opechona sp. (oral side), showing the spinous tegument. Scale $=50 \mu \mathrm{m}$.

Fig. 5. Scanning electron micrograph of the oral sucker of the metacercaria of Opechona sp.. Scale $=25 \mu \mathrm{m}$.

Fig. 6. Scanning electron micrograph of the acetabulum of the metacercaria of Opechona sp., note the 9 papillae. Scale $=25 \mu \mathrm{m}$. 


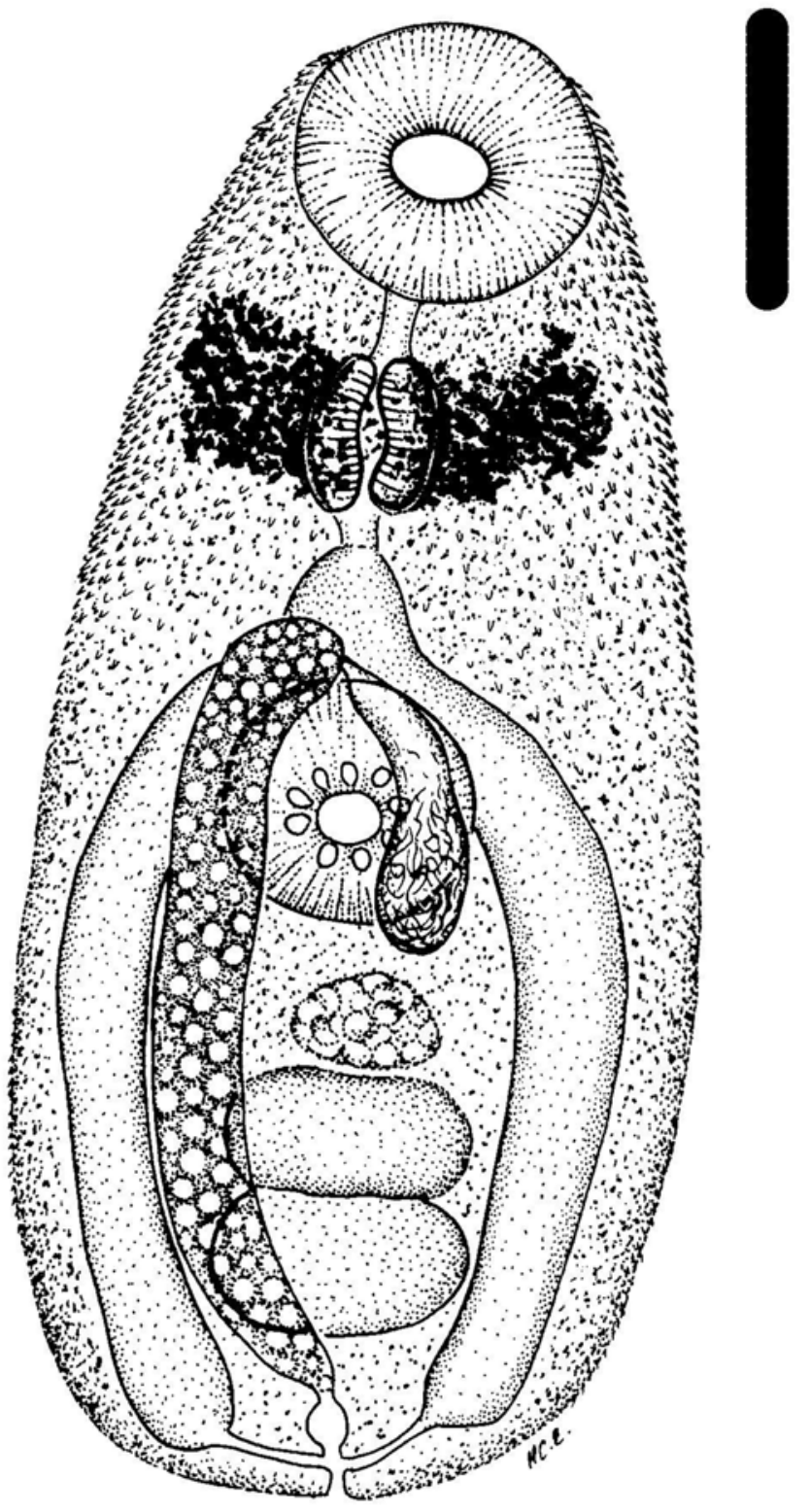

Fig. 7. Schematic drawing of the metacercaria of Opechona sp., ventral view. Scale $=50 \mu \mathrm{m}$.

It is interesting to note that the final host of the species $O$. chloroscombri (the fish Chloroscombrus chrysurus) is commonly found in association with medusae of $C$. lactea and L. lucerna (pers. obs.).

The members of the family Lepocreadiidae are common intestinal parasites of marine fishes
(Marcogliese, 1995). Cercariae are usually trichocercous and occelated and produced by rediae in snails (Bray, 1988). On the other hand, metacercariae are reported to occur in a variety of planktonic and bentonic animal groups, including reports of infested ctenophores and hydromedusae (e.g. Marcogliese, 1995; Martorelli, 1991, 2001; Gómez del Prado-Rosas 
et al., 2000). The members of Lepocreadiidae are known to live encysted in polychaetes, gastropods, bivalves, echinoids, and fish (Bray, 1988); and unencysted metacercariae have been reported for hydromedusae, ctenophores and mollusks (Bray, 1988). Only one case of Lepocreadiidae metacercariae encysted in "coelenterates" has recently been reported (Martorelli, 1996).

Although the complete life cycle of the present digenean is still unknown, we observed Chrysaora lactea and Beroe sp. feeding on Mnemiopsis maccradyi and also C. lactea feeding on Beroe sp., and it might be supposed that this could be one of the ways by which this medusa species is infected. Metacercaria of Bacciger sp. might be transferred from one intermediate host to another when the ctenophore Beroe ovata Chamisso et Eysenhardt, 1821 feeds on M. maccradyi infected with the parasite; in this situation the metacercariae remain unencysted in the mesoglea of the new host (SRM unplublished data).

Lepocreadiidae cercariae might also actively penetrate the medusae, losing their tail, and persisting inside their host without the formation of cysts (Martorelli, 1991). This active penetration could also explain the infection of, for instance, Lychnorhiza lucerna. The transference of the metacercaria from the gelatinous plankton to the definitive hosts (fish) is possible because gelatinous organisms may be important food items in the fish diet of the southwestern Atlantic (cf. Mianzan et al., 1996, 2001).

Arai (1997: 209) mentioned that in most cases it is not clear whether the animals feed on the medusae (parasitism) or are just using the jellyfish as a substrate or means of transport. The so-called metacercariae observed in these cases are not encysted, present active behavior and could therefore be feeding on the medusae. It is also noteworthy that the parasites were found in tissues in which a large quantity of nutrients is present (gastric filaments, gonads, canals and near pharynx). Although the parasitic condition is plausible, no abnormal development in the hosts or infected tissues was observed. The nematocysts observed in the tegument of the worms were the only identifiable response of the host $(C$. lactea) to the parasites.

This is the first report of digenean worms in scyphomedusae from the South Atlantic Ocean.

\section{ACKNOWLEDGEMENTS}

This project was undertaken as part of the first author's PhD. (supported by FAPESP 1999/05374-7), with a scholarship from "PósGraduação, Área Zoologia, IBUSP”. The project was also partly supported by FAPESP (2001/02626-7, 2003/02432-3,
(PROAP/Instituto de Biociências-USP), and CNPq (300271/2001-8). We wish to thank the staff of the Laboratório de Microscopia Eletrônica (IB-USP) and Mr. Enio Mattos for their assistance in making S.E.M. observations, and Dr. Fernando P.L. Marques (IBUSP) for suggestions in the early stages of the study, as well as for the facilities made available for depositing specimens at MZPC. We are also grateful to the Instituto Oceanográfico (USP) for providing collecting facilities at Cananéia. Messrs. Sergio N. Stampar (IB-USP) and Marcelo O. Soares (UFC) are also to be thanked for their help on the field. The authors further thank the two anonymous referees for their valuable suggestions.

\section{REFERENCES}

Abdallah, V. D.; Luque, J. L.; Alves, D. R. \& Paraguassú, A. R. 2002. Aspectos quantitativos das infrapopulações de metazoários parasitos da cavalinha, Scomber japonicus (Osteichthyes: Scombridae), do litoral do Estado do Rio de Janeiro. Rev. Univ. Rural, Sér. Ciênc. Vida, 22:104107.

Amato, J. F. R. 1983. Digenetic trematodes of percoid fishes of Florianópolis, Southern Brazil - Homalometridae, Lepocreadiidae, and Opecoelidae, with the description of seven new species. Rev. Bras. Biol., 43:73-98.

Arai, M. N. 1997. A Functional Biology of Scyphozoa. Chapman \& Hall, London. 316p.

Bouillon, J. 1987. Considérations sur le développement des Narcoméduses et sur leur position phylogénétique. IndoMalay. Zool., 4:189-278

Bray, R. A. 1988. A discussion of the status of the subfamily Baccigerinae Yamaguty, 1958 (Digenea) and the constitution of the family Fellodistomidae Nicoll, 1909. Syst. Parasit., 11:97-112

Bray, R. A. \& Gibson, D. I. 1990. The Lepocreadiidae (Digenea) of fishes of the north-east Atlantic: review of the genera Opechona Looss, 1907 and Prodistomum Linton, 1910. Syst. Parasit., 15:159-202.

Bray, R. A. \& Cribb, T. H. 1998. Lepocreadiidae (Digenea) of Australian coastal fishes: new species of Opechona Looss, 1907, Lepotrema Ozaki, 1932 and Bianium Stunkard, 1930 and comments on other species reported for the first time or poorly known in Australian waters. Syst. Parasit., 41:123-148.

Bush, A. O.; Lafferty, K. D.; Lotz, J. M. \& Shostak, A. W. 1997. Parasitology meets Ecology on its own terms: Margolis et al. Revisited. J. Parasitol., 83:575-583.

Child, C. A. \& Harbison, G. R. 1986. A parasitic association between a pycnogonid and a scyphomedusa in midwater. J. mar. biol. Ass. UK, 66:113-117.

Crowell, S. 1976. An edwardsiid larva parasitic in Mnemiopsis. In: Mackie, G.O., ed. Coelenterate Ecology and Behaviour. New York, Plenum Publishing Corp. p. 247-250.

Fabio, S. P. de 2001. Trematódeos parasitos de Cephalopholis fulva (Linnaeus, 1758) (Pisces: Serranidae) em Angra dos Reis, RJ, Brasil. Bol. Mus. Nac., NS, Zool., 456:1-8. 
GESAMP 1997. Opportunistic settlers and the problem of the ctenophore Mnemiopsis leidyi invasion in the Black Sea. GESAMP Rep Stud, 58:84 p.

Gómez del Prado-Rosas, M. C.; Segura-Puertas, L.; ÁlvarezCadena, J. N. \& Lamothe-Argumedo, R. 2000 Opechona pyriforme metacercaria (Trematoda: Lepocreadiidae) in Eirene lactea (Cnidaria: Hydroidomedusae) from a reef lagoon in the Mexican Caribbean Sea. An. Inst. Biol., Univ. nac. auton. Méx., Ser. Zool., 71:1-6.

Girola, C.V.; Martorelli, S.R. \& Sardella, N.H. 1992 Presencia de metacercarias de Monascus filiformis (Digenea: Fellodistomidae) en hidromedusas del Océano Atlántico Sur. Rev. chil. hist. nat., 65:409-415.

Harbison, G. R.; Biggs, D. C. \& Madin, L. P. 1977. The associations of Amphipoda Hyperiidea with gelatinous zooplankton - II. Associations with cnidarians, ctenophora and radiolaria. Deep Sea Res., 24:465-485.

Køie, M. 1975. On the morphology and life-history of Opechona bacillaris (Molin 1859) Looss 1907 (Trematoda, Lepocreadiidae). Ophelia, 13:63-86.

Lebour, M.V. 1916. Medusae as hosts for larval trematode. J. mar. biol. Ass. U.K., 11: 57-59.

Mahoney, R. 1973. Laboratory Techniques in Zoology. London, Butterworth \& Co., 404p.

Marcogliese, D. J. 1995. The role of zooplankton in the transmission of helminth parasites to fish. Rev. Fish. Biol. Fisher., 5:336-371.

Margolis, L.; Esch, G. W.; Holmes, J. C.; Kuris, A. M. \& Schad, G. A. 1982. The use of ecological terms in parasitology (Report of an ad hoc committee of the American Society of Parasitology). J. Parasit., 68:131133.

Martorelli, S. R. 1991. Primera cita de una cercaria tricocerca parásita de Dorsanum moniliferum (Mollusca, Buccinidae) para el Atlántico sud-occidental. Aportes al conocimiento de su ciclo de vida. Geotropica, 37:57-65.

Martorelli, S. R. 1996. First record of encysted metacercaria in hydrozoan jellyfishes and ctenophores of the Southern Atlantic. J. Parasit., 82:352-353.

Martorelli, S. R. 2001. Digenean parasites of jellyfish and ctenophores of the Southern Atlantic. Hydrobiol., 451:305-310.

Martorell,i S. R. \& Cremonte, F. 1998. A proposed three-host life history of Monascus filiformis (Rudolphi, 1819) (Digenea: Fellodistomidae) in the southwest Atlantic Ocean. Can. J. Zool., 76:1198-1203.

Mianzan, H. W.; Marí, N.; Prenski, B. \& Sánchez, F. 1996. Fish predation on neritic ctenophores from the Argentine continental shelf: a neglected food resource ? Fish. Res., 27:69-79.
Mianzan, H.W.; Pájaro, M.; Alvarez Colombo, G. \& Madirolas, A. 2001. Feeding on survival-food: gelatinous plankton as a source of food for anchovies. Hydrobiol., 451:45-53.

Moestafa, S. H. \& McConnaughey, B. H. 1966. Catostylus ouwensi (Rhizostomeae, Catostylidae) a new jellyfish from Irian (New Guinea) and Ouwensia catostyli n. gen., n. sp., parasitic in C. ouwensi. Treubia, 27:1-9.

Pagès, F. 2000. Biological associations between barnacles and jellyfish with emphasis on the ectoparasitism of Alepas pacifica (Lepadormorpha) on Diplulmaris malayensis (Scyphozoa). J. nat. Hist., 34:2045-2056.

Phillips, P. J. \& Levin, N. L. 1973. Cestode larvae from scyphomedusae of the Gulf of Mexico. Bull. mar. Sci., 23: 574-584.

Reimer, L. W.; Berger, C. H.; Heuer, B.; Lainka, H.; Rosenthal, I. \& Scharnweber, I. 1971. On the distribution of larvae of helminths in plankton animals of the North sea. Parasitologiya, 5:542-550.

Stunkard, H. W. 1969. The morphology and life-history of Neopechona pyriforme (Linton, 1900) n. gen., n. comb. (Trematoda: Lepocreadiidae). Biol. Bull., 136: 96-113.

Stunkard, H. W. 1980. The morphology, life cycle, and taxonomic relations of Lepocreadium areolatum (Trematoda: Digenea). Biol. Bull., 158:154-163.

Stunkard, H. W. 1983. The marine cercariae of the Woods Hole, Massachusetts region, a review and a revision. Biol. Bull., 164:143-162.

Thiel, M.E. 1976. Wirbellose Meerestiere als Parasiten, Kommensalen oder Symbionten in oder an Scyphomedusen. Helgol. Wiss. Meeresunt., 28:417-446. Vannucci-Mendes, M. 1954. Sôbre a larva de Dibothriorhynchus dinoi, sp. n. parasita dos Rhizostomata. (Cestoda Tetrarhynchidea). Arq. Mus. Paran., 4:47-82.

Wallet, M. \& Kohn, A. 1987. Trématodes parasites de poissons marins du littoral de Rio de Janeiro, Brésil. Mem. Inst. Oswaldo Cruz, 82:21-27.

Yip, S. Y. 1984. Parasites of Pleurobrachia pileus Müller (Ctenophora) from Galway Bay, Western Ireland. J. Plankt. Res., 6:107-122.

(Manuscript received 19 November 2004: revised 02 March 2005; accepted 30 June 2005) 